\title{
Inhibition of the Symbiotic Fungus of Leaf-Cutting Ants by Coumarins
}

\author{
Marizete F. P. Godoy ${ }^{a}$, Sandra R. Victor ${ }^{a}$, Adriana M. Bellini ${ }^{b}$, Gisleine Guerreiro ${ }^{b}$, Waldireny C. \\ Rocha ${ }^{b}$, Odair C. Bueno ${ }^{a}$, Maria J. A. Hebling ${ }^{a}$, Maurício Bacci Jr ${ }^{a}$, M. Fátima G. F. da Silva ${ }^{b}$, Paulo \\ C. Vieira ${ }^{b}$, João B. Fernandes ${ }^{b}$ and Fernando C. Pagnocca ${ }^{*, a}$ \\ ${ }^{a}$ Centro de Estudos de Insetos Sociais, Universidade Estadual Paulista, Campus de Rio Claro, CP 199, \\ 13506-900 Rio Claro - SP, Brazil \\ ${ }^{b}$ Departamento de Química, Universidade Federal de São Carlos, CP 676, 13565-905 São Carlos - SP, Brazil
}

Formigas cortadoras de folhas são consideradas pragas para a agricultura devido à grande quantidade de material vegetal utilizado por elas para cultivar um fungo simbionte que lhes serve de alimento e enzimas. O mutualismo entre o fungo e as formigas é um ponto a ser explorado quando se considera sua possível aplicação em métodos alternativos para o controle desses insetos. Sabendose que algumas plantas são naturalmente resistentes aos insetos fitófagos, alguns produtos naturais (metabólitos secundários) devem ser avaliados em relação às suas propriedades inseticidas e/ou fungicidas. Neste trabalho foram isoladas oito cumarinas de quatro espécies de plantas e o efeito no desenvolvimento do fungo simbionte das formigas cortadeiras Atta sexdens foi determinado. Com exceção da clausarina, todas as outras cumarinas foram inibitórias de $64 \mu \mathrm{g} \mathrm{mL}^{-1}$ à $80 \mu \mathrm{g} \mathrm{mL}^{-1}$ sendo que a xantiletina inibiu o fungo na concentração de $25 \mu \mathrm{g} \mathrm{mL}^{-1}$.

Leaf-cutting ants are known to be a serious pest for agriculture due to the high amounts of vegetal matter from crops used by them in order to cultivate a symbiotic fungus on which they rely for food and enzymes. The mutualism between the fungus and the ants is a point to be explored when alternative methods of control are being thought of. Considering that some plants are naturally resistant to phytophagous insects, some natural products (secondary metabolites) should be evaluated with respect to their insecticide and/or fungicide properties. In this paper we isolated eight coumarins from four different plant species and we determined their effect on the development of the symbiotic fungus of the leaf-cutting ant Atta sexdens. With the exception of clausarin, all the other coumarins were inhibitory from $64 \mu \mathrm{g} \mathrm{mL}^{-1}$ through $80 \mu \mathrm{g} \mathrm{mL}^{-1}$ and xanthyletin inhibited the fungus at $25 \mu \mathrm{g} \mathrm{mL}^{-1}$

Keywords: leaf-cutting ants, coumarins, symbiotic fungus inhibition

\section{Introduction}

Leaf-cutting ants, the dominant herbivores in the tropics, can be found from the Southern United States to Northern Argentina. ${ }^{1}$ They cultivate a symbiotic fungus for feeding using leaf fragments as substrate, thus damaging agriculture. $^{2}$

It is known that plants have several mechanisms to avoid herbivores, including a set of toxic chemicals. ${ }^{3}$ The presence of secondary plant metabolites toxic to the ants and/or to their symbiotic fungi may play an important role in whether the ants will cut such plants or not. ${ }^{4}$

Many of the most important crops cultivated in our country are exotic species, which have not had the

* e-mail: pagnocca@rc.unesp.br possibility of co-evolution with predators and as such are preferentially attacked. ${ }^{5}$

Different methods have been proposed for the control of these ants (organophosporus, pyrethroids and sulfluramid insecticides). However, problems with non-target animals, high chemical stability and environmental contamination are common and it is necessary to continue looking for new strategies to control these insects. ${ }^{6}$ The search for specific compounds directed against these ants and their microbial partners has been the focus of our studies during the past years and natural chemicals isolated from a variety of plant species were effective against the ants and inhibited the growth of their symbiotic fungus or both. ${ }^{6-15}$

Among the several biological properties of coumarins we can find dermal photosensitising, estrogenic, antimicrobial, vasodilator, molluscicidal, antihelmintic, 
sedative and hypnotic, analgesic and hypothermic activities, ${ }^{16,17}$ but they have been associated mainly with anticoagulant activity. ${ }^{18}$ Indeed, they are widely found in several botanical families such as Rutaceae, Apiaceae, Asteraceae, Fabaceae, Oleaceae, Moraceae and Thymeleaceae and it seems to correlate with their action as phytoalexins. Repellent action to beetles and other terrestrial invertebrates and the inhibition of both sporulation and the growth of some fungal plant pathogens by some coumarins were described by Weinmann. ${ }^{19}$

The aim of this study was to analyze the activity of eight coumarins isolated from different plant species on the development of the symbiotic fungus of the leaf-cutting ant Atta sexdens rubropilosa.

\section{Experimental}

\section{Preparation and fractioning of crude extracts}

Different parts of plants were ground to powder, dried at $40{ }^{\circ} \mathrm{C}$ and percolated with a set of organic solvents (hexane, dichloromethane and methanol) during 72 hours three times each at room temperature for three days, followed by the evaporation of the solvent under reduced pressure at $40{ }^{\circ} \mathrm{C}$. The crude extracts were fractionated through flash chromatography under vacuum with silica gel and eluted with solvents of increasing polarity (hexane, dichloromethane, ethyl acetate and methanol). They were then purified through different techniques including column chromatography, preparative TLC and HPLC.

\section{Coumarins}

Angelicin (1), suberosin (2), xanthoxyletin (3) and clausarin (4) were isolated from the methanol extract of the roots of Citrus limonia. Isopimpinellin (5) was isolated from the dichloromethane extract of the roots of Adiscanthus fusciflorus Ducke. Umbelliferone (6) was isolated from the hydroalcoholic extract of the barks of Picramnia teapensis, xanthyletin (7) and 7-hydroxy-3(1'1'-dimethylallyl)-8-methoxycoumarin (8) were isolated from the dichloromethane extract of the stems of Pilocarpus riedelianus.

All the coumarins were identified through spectrometric techniques such as ${ }^{1} \mathrm{H} \mathrm{NMR},{ }^{13} \mathrm{C}$ NMR, MS and IR and compared to literature data for $(\mathbf{1}) ;{ }^{20}(\mathbf{2}) ;{ }^{21-23}$ (3) ${ }^{22,24}(\mathbf{4}) ;{ }^{22}(\mathbf{5}) ;{ }^{22,} 23,25-27(6) ;{ }^{28}(\mathbf{7}) ;{ }^{28,}{ }^{29}(\mathbf{8}){ }^{30}$

\section{Fungus}

The fungus Leucoagaricus gongylophorus (Singer)
Möller (syn Rozites gongylophorus) was isolated from a laboratory nest of Atta sexdens L.

The medium for fungus maintenance and methods for the bioassays were previously described. ${ }^{10}$ One $\mathrm{mL}$ of dichloromethane solution of each coumarin was added to $9.0 \mathrm{~mL}$ of culture medium composed of $\left(\mathrm{g} \mathrm{L}^{-1}\right)$ : glucose, 10.0; sodium chloride, 5.0; peptone, 5.0; malt extract, 10.0 and agar, 15.0. Control tubes received $1.0 \mathrm{~mL}$ of dichloromethane and $9.0 \mathrm{~mL}$ of medium. After the addition, the tubes were autoclaved at $121^{\circ} \mathrm{C}$ by $15 \mathrm{~min}$ and then slanted. The final concentration of each coumarin in $\mu \mathrm{g}$ $\mathrm{mL}^{-1}$ was: $\mathbf{1}=72 ; \mathbf{2}=64 ; \mathbf{3}=70 ; \mathbf{4}=75 ; \mathbf{5}=80 ; \mathbf{6}=65 ; \mathbf{7}=25$ and $\mathbf{8}=75$. The fungal suspension was prepared by transferring aseptically pieces of the mycelia (obtained from 1-month-old culture growing in slant culture) to an all-glass tissue grinder containing sterile peptone $\left(1 \mathrm{~g} \mathrm{~L}^{-1}\right)$ and gently fragmented. One $\mathrm{mL}$ of this suspension was spread onto the surface of the agar slant and incubated at $25( \pm 1){ }^{\circ} \mathrm{C}$ for 30 days. The assays were run twice (two sets of five tubes each). Controls with and without solvent as well as with PBO (9) (commercial piperonil butoxide Pirisa Piretro Industrial, 97LO106IO) were run simultaneously. Fungal growth was estimated macroscopically on the basis of the mycelial surface and density using the modal value.

\section{Results and Discussion}

Figure 1 shows the molecular structure of the isolated coumarins and on Table 1 we can see the effects of the coumarins on the fungal growth. Except for clausarin (4), which had no effect on the fungal development at a concentration of $75 \mu \mathrm{g} \mathrm{mL}^{-1}$, all the others inhibited the fungus at different degrees. Thus, at $72 \mu \mathrm{g} \mathrm{mL}^{-1}$, angelicin (1) was responsible for a moderate $(40 \%)$ inhibition of fungal growth whereas an inhibition of $60 \%$ was achieved with umbelliferone (6) at $65 \mu \mathrm{g} \mathrm{mL} \mathrm{m}^{-1}$. Strong inhibition (80\% at $\left.75 \mu \mathrm{g} \mathrm{mL}^{-1}\right)$ was observed with 7-hydroxy-3-(1',1'dimethylallyl)-8-methoxycoumarin (8) and total inhibition of fungal growth was observed with suberosin (2), xanthoxyletin (3) and isopimpinellim (5) at concentrations ranging from 64 to $80 \mu \mathrm{g} \mathrm{mL} \mathrm{mL}^{-1}$. Unfortunately, we did not have enough material to determine whether suberosin, xanthoxyletin and isopimpinellim could be inhibitory at a lower concentration. Victor ${ }^{31}$ had shown total inhibition of the fungus in the presence of xanthyletin (7) at concentrations of 100 and $50 \mu \mathrm{g} \mathrm{mL}^{-1}$. The same effect was now observed at $25 \mu \mathrm{g} \mathrm{mL}^{-1}$ showing that this compound should be better evaluated in respect to its potential in the control of these insects. 


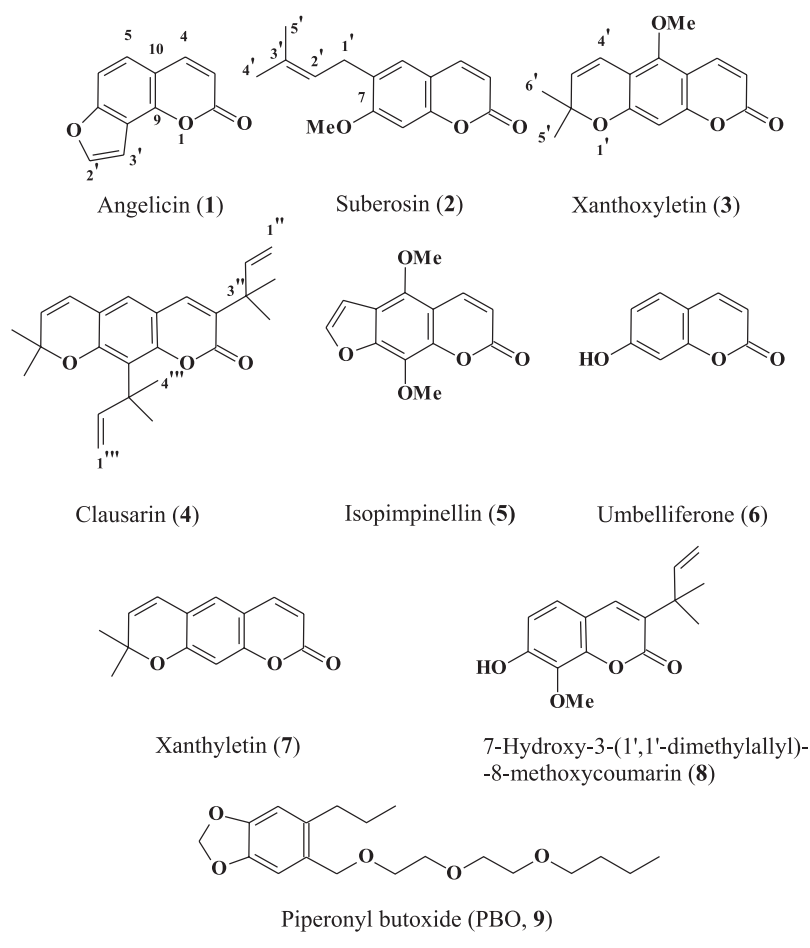

Figure 1. Molecular structures of coumarins and commercial piperonyl butoxide.

Table 1. Inhibitory effect of natural coumarins on symbiotic fungus of leaf-cutting ant Atta sexdens rubropilosa

\begin{tabular}{ccc}
\hline Compounds & $\begin{array}{c}\text { Concentration } \\
\left(\mu \mathrm{g} \mathrm{mL}^{-1}\right)\end{array}$ & $\begin{array}{c}\text { Inhibition of fungal } \\
\text { growth }(\%)^{\mathrm{a}, \mathrm{b}}\end{array}$ \\
\hline $\mathbf{1}$ & 72 & 40 \\
$\mathbf{2}$ & 64 & 100 \\
$\mathbf{3}$ & 70 & 100 \\
$\mathbf{4}$ & 75 & 0 \\
$\mathbf{5}$ & 80 & 100 \\
$\mathbf{6}$ & 65 & 60 \\
$\mathbf{7}$ & 25 & 100 \\
$\mathbf{8}$ & 75 & 80 \\
PBO $^{\mathrm{c}}$ & 50 & $\geq 80$
\end{tabular}

${ }^{\mathrm{a}}$ Control with and without solvent $=0 \%$ inhibition of fungal growth; ${ }^{\mathrm{b}}$ Dry-weight of inoculum $=6.2 \pm 0.3 \mathrm{mg} \mathrm{mL}^{-1} ;{ }^{\mathrm{c}}$ Control $=\mathrm{PBO}=$ Piperonyl butoxide.

Five out of the eight coumarins assayed were isolated from the roots of Citrus limonia and Adiscanthus fusciflorus. Natural coumarins are synthesized by plants as a response to injury during the wilting process, diseases or drying and accumulate on the surface of leaves, fruits and seeds. According to Ojala ${ }^{32}$ their presence in the roots may provide a tool against microbial invasion.

Attempts to correlate structure and antimicrobial activity of coumarins were made by some authors. Kayser and Kolodziej ${ }^{33}$ reported that highly oxygenated coumarins and the positions of the polar hydroxyls and of the less polar methoxy groups on the aromatic nucleus are important for antibacterial activity. Yet, according to Dini et al. (apud Sardari et al..$^{34}$ ) the occurrence of the aromatic hydroxy group and/or ether or ester groups at positions 6 or 7 of the basic structure are important for antifungal action. For them, alkylated derivatives of 7hydroxycoumarins can have both antifungal and antibacterial properties. On the other hand, Sardari et al. ${ }^{34}$ did not find antifungal activity of coumarins with a hydroxy group at position 7, as observed with umbelliferone, which showed low activity against Candida albicans, Cryptococcus neoformans and Aspergillus niger but they found a relationship between antifungal activity and the presence of free 6-OH and 6-OMe. The results of Sardari et al..$^{34}$ were confirmed by Ojala et al. ${ }^{35}$ with $C$. albicans, A. niger and Saccharomyces cerevisiae but not for the phytopathogenic fungus Fusarium culmorum to which umbelliferone was highly inhibitory. So, if some structure-activity relationship can be made, the hypothesis about a possible species-specific activity cannot be discarded.

Except for clausarin (4) our results showed that the seven linear coumarins assayed inhibited the symbiotic fungus of A. sexdens at low concentrations whereas a low inhibition was achieved with angelicin. Since angelicin was the only angular coumarin assayed in this work it was not possible to establish at this moment any relationship between antifungal activity and linearity. Also the occurrence of prenyl and $\mathrm{MeO}$ groups linked to the basic structure of coumarins should be better studied in order to determine if they are important or not for the antifungal activity described here.

\section{Acknowledgments}

The authors are grateful to FAPESP and CNPqPRONEX, for the financial support as well as for the scholarships and to Jonathan Burgess and Cybel Burgess for the English review.

\section{References}

1. Mariconi, F. A. M.; As Saúvas, Ares: São Paulo, 1970.

2. Weber, N. A.; Memoirs of the American Philosophical Society 1972, 92, 17.

3. Ishaaya, I. In Insect Plant Interaction; Miller, J.R.; Miller, T. A, eds.; Springer-Verlag: New York, 1990.

4. Hubbell, S. P.; Wiemer, D. F. In Social Insects in the Tropics; Jaisson, P., ed., University of Paris Press: Paris, 1983.

5. Bueno, O. C.; Hebling, M. J. A.; Castro, S. L. R.; Silva, O. A.; Pagnocca, F. C; Anais do Encontro de Mirmecologia, Viçosa, Brazil, 1989, 24 
6. Hebling, M. J. A.; Bueno, O. C.; Maroti, P. S.; Pagnocca, F. C.; Silva, O. A.; J. Applied Ent. 2000, 124, 249.

7. Acácio-Bigi, M. F. M.; Hebling, M. J. A.; Bueno, O. C.; Pagnocca, F. C., da Silva, O. A.; Fernandes, J. B.; Vieira P. C.; Rev. Bras. Entom. 1998, 41, 239.

8. Hebling, M. J. A.; Maroti, P.S; Bueno, O. C.; Silva, O.A.; Pagnocca, F.C.; Bull. Entom. Res, 1996, 86, 253.

9. Bueno, O. C; Hebling, M. J. A.; Silva, O. A.; Matenhauer, A. M. C.; J. Appl. Entom. 1995, 119, 341.

10. Pagnocca, F. C.; Silva, O. A.; Hebling, M. J. A; Bueno, O. C.; Bull. Entomol. Res. 1990, 80, 349.

11. Pagnocca, F. C.; Ribeiro, S. B.; Torkomian, V. L. V.; Hebling, M. J. A.; Bueno, O. C.; Silva, O. A.; Fernandes, J. B.; Vieira, P. C.; da Silva, M. F. G.F.; Ferreira, A. G.; J. Chem. Ecol. 1996 22, 1325 .

12. Victor, S. R.; Crisostomo, F. R.; Bueno, F. C.; Pagnocca, F. C.; Fernandes, J. B.; Correa, A. G.; Bueno, O. C.; Hebling, M. J. A.; Bacci Jr, M.; Vieira, P. C.; da Silva, M. F. G. F.; Pest. Manag. Sci. 2001, 57, 603.

13. Rodríguez-Gamboa, T.; Victor, S. R.; Fernandes, J. B.; Rodrigues-Filho, E.; da Silva, M. F. G. F.; Vieira, P. C.; Pagnocca, F. C.; Bueno, O. C.; Hebling, M. J. A.; Castro, C. O.; Phytochemistry 2000, 55, 837.

14. Rodríguez-Gamboa, T.; Fernandes, J. B.; Rodrigues-Filho, E.; da Silva, M. F. G. F.; Vieira, P. C.; Barrios Ch., M.; Castro, C. O.; Victor, S. R.; Pagnocca, F. C.; Bueno, O. C.; Hebling, M. J. A.; J. Braz. Chem. Soc. 2001, 12, 386.

15. Godoy, M. F. P.; Souza, R. C.; Zancul, M. S.; Pagnocca, F. C.; Fernandes, J. B.; Bueno, O. C.; Hebling, M. J. A.; Bacci Jr., M.; da Silva, M. F.G. F.; Vieira, P. C.; Arq. Inst. Biol. 2002, 69 , supl., 192

16. Soine, T.O.; J. Pharm. Sci. 1964, 53, 231.

17. O’Kennedy, R.; Thornes, R. D.; Coumarins - Biology, Applications and Mode of Action, John Wiley \& Sons Ltda: Chichester, 1997.

18. Simões, C. M. O.; Schenkel, E. P.; Gosmann, G.; Mello, J. C. P.; Mentz, L. A.; Petrovick, P. R.; eds.; Farmacognosia: Da Planta ao Medicamento, $4^{\text {th }}$ ed., Editora da UFSC: Florianópolis, SC; Editora da UFRS: Porto Alegre, RS, 2002.
19. Weinmann, I. In Coumarins - Biology, Applications and Mode of Action, O’Kennedy, R.; Thornes, R. D., eds., John Wiley \& Sons Ltda: Chichester, 1997, p. 1-22.

20. Kulkarni, G. H.; Haribal, M. M.; Sabata, B. K.; Indian J. Chem. 1980 19B, 424, (CA 93: 66153d).

21. Bhide, K. S.; Mujumdar, R. D.; Rao, A. V. R.; Indian J. Chem. 1977, 15B, 440 (CA 87: 180653d)

22. Gray, A. I.; Waterman, P. G.; Phytochemistry 1978, 17, 845.

23. Prakash, D.; Roy, K.; Kapil, R. J.; Popli, S. P.; Phytochemistry 1978, 17, 1194.

24. Martinez, E. A.; Reyes, R. E.; Gonzalez, A. G.; RodriguezLuis, F.; An. Acad, Soc. Espan. Fis. Quím., Ser. B. 1967, 63, 197 (CA 67, 47086f)

25. Sharma, P. N.; Shoeb, A.; Kapil, R. S.; Popli, S. P.; Indian J. Chem. 1981 20B, 936 (CA 96, 65684c, 1982)

26. Wang, C. T.; Chang, H. J.; Shan-his Hsiu I Yao 1981 10, 51 (CA. 95, 175631v)

27. Dreyer, D. L.; Lee, A.; Phytochemistry 1972, 11, 763.

28. Razdan, T. K.; Qadri, B.; Harkar, S.; Waight, E. S.; Phytochemistry 1987, 26, 2063.

29. Joshi, B. S.; Gawad, D. H.; Ravindranath, K. R.; Proc. Indian Acad. Sci. 1978 87A, 173 (CA 89, 215258p)

30. Del Castillo, J. B.; Luis, F. R.; Secundino, M.; Phytochemistry 1984, 23, 2095.

31. Victor, S. R.; Ph.D. Thesis, Universidade Estadual Paulista, Rio Claro, Brazil, 2001

32. Ojala, T.; Biological Screening of Plant Coumarins. Academic Dissertation, Faculty of Science of the University of Helsinki, 2001.

33. Kayser, O.; Kolodziej, H.; Z. Naturforsch 1999, 54, 169.

34. Sardari, S.; Mori, Y.; Horita, K.; Micetich, R. G.; Nishibe, S.; Daneshtalab, M.; Bioorg. Med. Chem. 1999, 7, 1933.

35. Ojala,T.; Remes, S.; Haansuu, P.; Vuorela, H.; Hiltunem, R.; Haahtela, K.; Vuorela, P. J. Ethnopharmacol. 2000, 73, 299.

Received: November 10, 2003

Published on the web: March 15, 2005

FAPESP helped in meeting the publication costs of this article. 